\title{
"Overtime" and the Academic Librarian
}

\begin{abstract}
Although librarianship is a profession and cannot therefore always be fulfilled by a specific number of clock hours, the amount of time spent on any job is an important morale factor and warrants management concern. To determine practices in their administration of "overtime," the college and university libraries in New York State were polled, and the results of the survey are reported; conclusions are proposed.
\end{abstract}

$\mathrm{T}_{\mathrm{t}}$ HE DECISION to develop this study of the handling of "overtime" performed by academic librarians was primarily a result of the fact that very little material was available on the subject. A literature search covering the period 19551964 failed to uncover any specific study or survey on the number of hours worked by college and university librarians. Indeed, if touched upon at all, it was only by implication in relation to some other subject. ${ }^{1}$ The topic is similarly ignored in the educational literature for the same period, while the personnel management literature in the field of business administration deals with it almost exclusively in relation to the wage-earner, or work$\mathrm{er}$, as differentiated from the profession-

\footnotetext{
1 Arthur M. MeAnally, "Social Pressures and Academic Librarianship," American Library Association Bulletin, LVI (Febrary 1962), 159-62ff.

Arthur M. McAnally, "Privileges and Obligations of Academic Status," College and Research Libraries, XXIV (March 1963), 102-108. McAnally notes the problem which an average work week of thirtyeight hours ereates for librarians who wish to teach or understake research. The performance of additional work (i.e., overtime) would obviously aggravate this problem.

Mary E. Scott, "Weekend Workers," Library Journal, LXXXVII (May 1, 1962), 1742-45. Scott's study, establishing the general opposition to Sunday openings, would seem to imply that such work is considered overtime.
}

Mr. Doerrer is a graduate student in Syracuse University. The author acknowledges the assistance of $\mathrm{Mr}$. Umeshdetta Sharma in the preparation of this paper. al. ${ }^{2}$ Studies were found, however, in the fields of public and state librarianship which included the topic of overtime. ${ }^{3}$

What the literature search did reveal was that the question of hours of work, regular or overtime, performed by academic librarians was inextricably bound up with the status of the librarian as a professional. References were also found which related this question of hours of work to the subject of the continuing professional development of the librarian. What would seem to be the prevailing attitude toward the performance of overtime by professionals is expressed by the following quotations: "The professional man is not concerned with hours. He is concerned with the performance of certain services and the pursuit of that truth which is directly related to his professional area of interest. The life of scholarship, the drudgery and the thrill of research, the pur-

\footnotetext{
2 The majority of references located dealt primarily with the subject of overtime in relation to wages, productivity, and the shorter work week advocated by some labor unions. There was no mention of voluntary overtime ever being performed by any rank-and-file worker.

${ }^{3}$ Kathleen B. Stebbins, Personnel Administration in Libraries (New York: Searecrow Press, 1958), p. 209-93.

American Library Association. Library Administration Division. Personnel Administration Section. State Library Personnel Practices Committee, Personnel Practices in State Libraries and State Library Extension Agencies. A report of a study undertaken by the State Library Personnel Practices Committee (Trenton: New Jersey State Department of Education, 1961), p. 15.
} 
suit of truth; the exchange, the sharpening, the clash of ideas; professional growth-all these are demands that must be met over and above hourly requirements." ${ }^{4}$ "He must realize that he cannot turn off his mind when the day's work is done, but that if he is to be successful both as a person and as a librarian, he must continue to educate himself." "But a fifty-, sixty- or seventyhour week brings the librarian no overtime pay. Nor does he ask for it."

This deprecation of the relevancy of hours of work, as opposed to the nature of the work, for a professional is seemingly borne out by similar statements found in the literature of business personnel management. Lee E. Danielson records the following definition of a professional as given by an engineer, "I would say that the professional person finds his satisfaction in his job. He enjoys his work and gives himself more to his work. He doesn't end the job after putting in his eight hours a day. He takes his job home with him."7 Thus, these statements would seem to imply that it is immaterial to the professional whether he works a thirty-five- or a seventy-hour week, so long as he accomplishes his job. This being the case, it would appear that the question of overtime should never be raised in relation to professionals, e.g., academic librarians.

Despite this apparent dedication to the "ideals of service to the point of individual self-sacrifice," 8 the subject of overtime for professionals was consid-

- Russell H. Seibert, "Status and Responsibilities of Academic Librarians," College and Research Libraries, XXII (July 1961), 253.

${ }^{8}$ Stebbins, op. cit., p. 100.

'Harold Lancour, "The Librarian's Search for Status," Seven Questions about the Profession of Librarianship, ed. by Philip H. Ennis and Howard W. Winger (Chicago: The University of Chicago Press, 1962), p. 80.

${ }^{7}$ Lee E. Danielson, Characteristics of Engineers and Scientists (Ann Arbor: Bureau of Industrial Relations, The University of Michigan, 1960), p. 12.

${ }^{8}$ Kaspor D. Naegele and Elaine C. Stolar, "Income and Prestige," Library Journal, LXXXV (September $1,1960), 2891$. ered sufficiently relevant to be included in discussions of personnel policies and practices of state and public libraries. The ACRL Standards for College Libraries state that, "The professional librarian is defined as one holding a graduate library degree." ${ }^{\prime 9}$ This would seem to establish the fact that the academic librarian is no more nor less a professional than any other librarian. A bit of reflection will demonstrate that this must be so. A librarian in a college or university library does not cease to be a professional if he joins the staff of a public or state library. Therefore, it would appear to follow that academic libraries should also have some policies covering this subject, if no more than a restatement of the "professional" attitudes cited above.

In the absence of published studies, a brief questionnaire was prepared and distributed to ninety-three accredited four-year colleges and universities in New York State. This figure included campuses of the State University and colleges operated by religious orders (or under denominational control) as well as privately controlled institutions. Seventy-six questionnaires, or approximately 82 per cent were returned. Since some confusion seemed to exist as to a definition of "overtime" as opposed to the performance of those tasks which contribute to the continuing development of a professional person, the following limiting definition of "over-time" was included in the questionnaire:

"Overtime," for the purposes of this survey, is defined as directly job-connected work performed in excess of the institution's normal work week as established by the professional staff member's contract, the job description, or other official statement. Time spent upon any of the numerous activities which contribute to self improve-

- ACRL Committee on Standards, "Standards for College Libraries," College and Research Libraries, XX (July 1959), 275. 
TABLE 1

Relationship of Size of Library to EXISTENCE OR NON-EXISTENCE OF OfFICIAL Overtime Policy

\begin{tabular}{l|c|c|c}
\hline \hline $\begin{array}{c}\text { No. of } \\
\text { Libraries }\end{array}$ & $\begin{array}{c}\text { Total No. } \\
\text { of Students }\end{array}$ & $\begin{array}{c}\text { Official } \\
\text { Overtime } \\
\text { Policy }\end{array}$ & $\begin{array}{c}\text { No } \\
\text { Official } \\
\text { Overtime } \\
\text { Policy }\end{array}$ \\
\cline { 1 - 2 } $26^{\circ}$ & $\begin{array}{c}250-1,000 \\
25 .\end{array}$ & 8 & 17 \\
$10 . \quad$ & $1,000-2,500$ & 11 & 14 \\
5 & $2,500-5,000$ & 7 & 3 \\
$10^{\circ}$ & $5,000-10,000$ & 5 & 0 \\
Totals 76 & $10,000-32,000$ & 5 & 4 \\
\hline
\end{tabular}

* One library in each of these groups did not answer this question.

ment or professional development should not be considered as "overtime."

The results of the survey are summarized in the accompanying tables. A few of the major facts established are cited here.

Thirty-six libraries (47 per cent) stated that they had an official policy on overtime. Of these, thirty-two said that their staff members were formally informed of the provisions of the policy. While a slightly higher number, thirtyeight ( 50 per cent), said they had no policy, a total of fifty-six (74 per cent) indicated that their professional staff members were requested to perform overtime. An even higher number, sixtysix ( 87 per cent), said that their professionals performed overtime wholly on their own initiative. ${ }^{10}$ In the case of both categories of overtime, the majority indicated that compensatory time was authorized. ${ }^{11}$ A smaller number, however, reported any type of compensation for voluntary overtime than the number reporting compensation for required overtime. Of the total number reporting the performance of voluntary overtime, twenty-two reported that they would consider this as a factor in evaluation for a merit increase; twenty-three that they would consider it in evaluation for promotion. ${ }^{12} \mathrm{~A}$ final question was designed to produce some indication of who performed the overtime (i.e., all or only some of the staff), the frequency of performance, and whether or not it was performed in relation to the work load. Unfortunately, the large number of libraries which checked only one of the three categories would seem to indicate that the question had not been phrased with sufficient clarity. A space was al-

\footnotetext{
${ }^{10}$ One library indicated that they did not know whether professional staff members performed voluntary overtime or not.

11 Several indicated by comment that the taking of compensatory time was authorized, but left to the discretion of the individual concerned. Some added that time was often not taken.

12 This question was left unanswered by a considerable number of libraries. Some, however, indicated that they did not have merit increases, hence the question was inapplicable. This may well have been true of others who simply failed to answer the question without comment. The same circumstances would apply to libraries with such a small professional staff that promotions would be infrequent, if at all.
}

TABLE 2

Relationship of Existence of Official Overtime Policy to Performance of, and Compensation for, Required Overtime

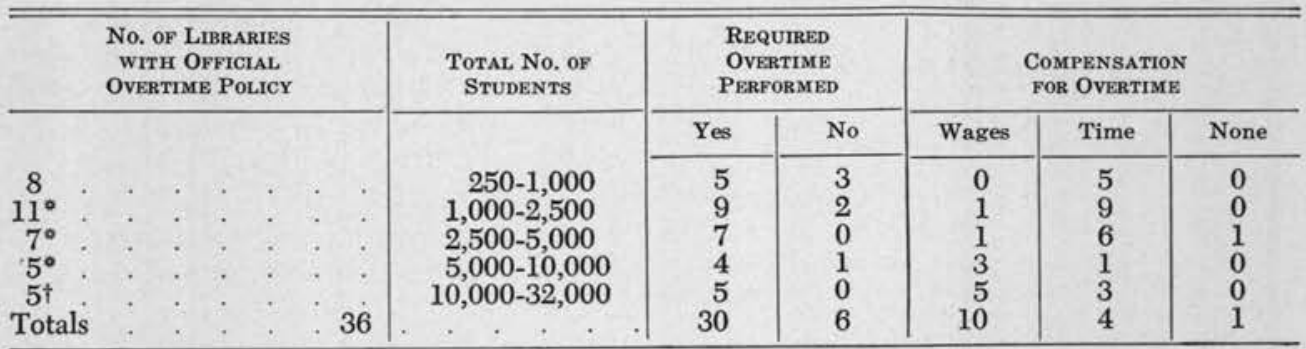

* 1 ehecked both wages and time.

† 3 checked both wages and time. 
lowed for comments by those wishing to make them. A number of the denominational colleges indicated that members of their religious orders made no distinction between regular and overtime hours in the performance of their library duties. Some also indicated that their religious workers served without remuneration. Comments from several of the state university campuses indicated that the status of the librarian (as regards personnel policies and practices) is currently in a state of flux as a result of a recent change from civil service to unclassified status. The majority stated that they did have an official policy concerning overtime, that their professionals were requested to perform overtime at one time or another, and that voluntary overtime was performed. This indicated that the practices of state universities are quite similar to those of private institutions in this area. From the data received, no valid generalization may be made as to the state libraries' policy toward considering voluntary overtime in evaluation for merit increases or promotions.

Despite the survey's deficiency in the one area noted, it was felt that the percentage of replies received was high enough to permit some conclusions to be drawn concerning the handling of overtime performed by professional librarians.
In spite of assertions to the contrary, the professional is concerned with hours. To state that overtime, required or voluntary, is performed obviously implies that there is some standard period of work which is considered as regular time. Another illustration of the fact that the problem of overtime is recognized and dealt with (again in practice if not in theory) in academic libraries is found in several comments on the questionnaires which indicated that work performed in the evenings, on weekends, and/or on holidays, is considered as overtime, as well as additional hours beyond those specified in the staff member's contract. The fact that the majority of libraries allow compensatory time for the performance of overtime also demonstrates that in actuality it is recognized that even a "professional" can be expected to devote only a reasonable number of hours to his place of duty without relief. This is in no way an attempt to deny that a professional attitude toward the job does and should exist. It is here that the difference between "overtime" and a "professional attitude toward the job" or a "responsibility for continuing professional development" must be made clear. To illustrate by a purposely exaggerated example, let us take the case of two librarians, both of whom work a "regular" thirty-seven hour week. One devotes an

TABLE 3

Relationship of Existence of Official Overtime Policy to Performance of, and Compensation for, Voluntary Overtime

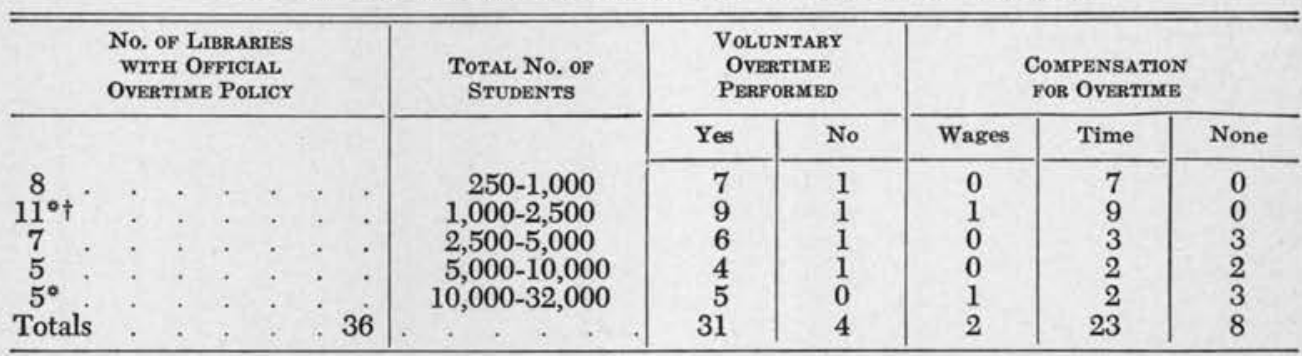

* 1 checked both wages and time.

$\dagger 1$ did not answer these questions. 
TABLE 4

Relationship of Non-Existence of Official Overtime Policy to Performance of, and Compensation for, Required Overtime

\begin{tabular}{|c|c|c|c|c|c|c|c|c|c|c|}
\hline \multicolumn{5}{|c|}{$\begin{array}{c}\text { No. OF LIBRARIES } \\
\text { WITHOUT OFFICIAL } \\
\text { OVERTIME PoLICY }\end{array}$} & \multirow{2}{*}{$\begin{array}{c}\begin{array}{c}\text { Total No. of } \\
\text { Students }\end{array} \\
250-1,000\end{array}$} & \multicolumn{2}{|c|}{$\begin{array}{c}\text { REQUIREd } \\
\text { OvERTIME } \\
\text { PERForMEd }\end{array}$} & \multicolumn{3}{|c|}{$\begin{array}{l}\text { COMTPENSATION } \\
\text { FOR OVERTIME }\end{array}$} \\
\hline & & & & & & Yes & No & Wages & Time & None \\
\hline $\begin{array}{c}17 \\
14^{\circ} \\
3 \\
0 \\
4 \\
\text { Totals }\end{array}$ & $\vdots \vdots$ & : & : & $\therefore$ & $\begin{array}{c}250-1,000 \\
1,000-2,500 \\
2,500-5,000 \\
5,000-10,000 \\
10,000-32,000\end{array}$ & $\begin{array}{r}12 \\
8 \\
1 \\
0 \\
3 \\
24\end{array}$ & $\begin{array}{r}5 \\
6 \\
2 \\
0 \\
1 \\
14\end{array}$ & $\begin{array}{l}0 \\
1 \\
0 \\
0 \\
0 \\
1\end{array}$ & $\begin{array}{r}10 \\
8 \\
0 \\
1 \\
2 \\
21\end{array}$ & $\begin{array}{l}2 \\
0 \\
0 \\
0 \\
1 \\
3\end{array}$ \\
\hline
\end{tabular}

* 1 checked both wages and time.

additional twenty hours per week to a course in a foreign language, attending meetings of a professional organization, reviewing new books, participating on university committees, etc. The other serves an additional twenty-hour tour of duty at the reference desk. If we are willing to accept the definition of overtime as directly job-connected work, the second librarian has clearly worked overtime.

The point has also been made that preoccupation with the number of hours worked (i.e., overtime) is inimical to the librarian's position in the academic community (i.e., faculty status). To meet this objection and further clarify the difference between overtime and the performance of one's obligations to the life of scholarship, let us consider the case of two faculty members, both of whom have a "normal" work week of four subjects, or twelve class hours. The first devotes an additional thirty hours per week to keeping abreast of new developments in his field, updating and revising his lectures, individual conferences with his students, participating in university affairs through committees, informal conferences, etc. The second spends his additional thirty hours per week in classroom teaching. It is fairly safe to assume that our second faculty member will certainly feel that he has worked overtime. ${ }^{13}$ The implication of

13 The fictitious examples were deliberately made "black-and-white" to illustrate the point. There are obviously "gray" areas between overtime and professional responsibility, such as the case of a librarian who reviews new books during her additional tour of duty.

TABLE 5

Relationship of Non-Existence of Officlal Overtime Policy to Performance of, and Compensation for, Voluntary OVertime

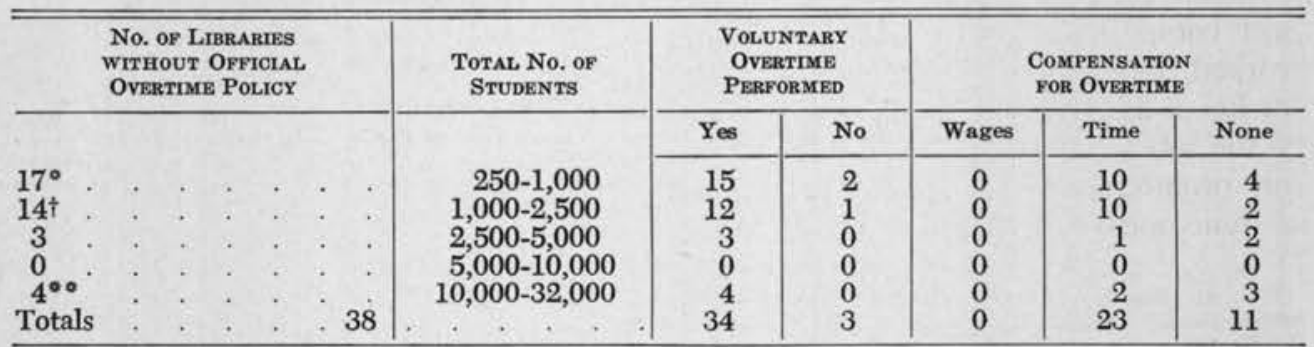

* 1 did not answer the question on compensation.

$\dagger 1$ did not know if voluntary overtime was performed or not.

** 1 checked both time and no compensation. 
this illustration (i.e., that faculty members are concerned about the number of hours they work) is substantiated by a recent survey of faculty satisfactions and dissatisfactions at New York University. In response to a question which asked what factors would be of importance in considering a position at another university, the extent of teaching load ranked fourth from the top in the order of reasons given, having a rating of 6.4 on the 9-point scale used. ${ }^{14}$

If we are now willing to grant that the concept of overtime (properly defined) is as valid in the professional world as elsewhere, to what then may the general reluctance of many to accepting its relevancy be attributed? One clue may be found in the nature of the work performed by a professional. In general, a professional is considered to render a service through his profession. $\mathrm{He}$ is not thought of, except colloquially, as simply "doing a job." In accordance with this concept, the professional is rewarded for his service, not his time. A librarian is hired to fill a position. Ideally, he is paid for the performance of the duties which this position entails, not for the number of hours he spends at his desk or in the library. Thus there is a very real, and justified, reluctance to consider the number of hours worked as being as relevant as the service rendered in the evaluation of professional performance and in the computation of professional compensation. As two of the librarians surveyed expressed it, "A professional person should not always expect compensation for additional hours worked, but should be paid adequately for his or her services"; and "The quality of the job a person does is the criterion for promotions. The mere putting in of time means nothing in itself." Ken-

14 J. D. Russell, "Faculty Satisfactions and Dissatisfactions," Journal of Experimental Education, XXXI (December 1962), 138. A high rating on the scale indicated a high degree of satisfaction or importance. A rating of 5 was considered the neutral point.
TABLE 6

Voluntary Overtime Constdered as a Factor in Evaluation of PersonNel for MertT INCREASES OR Promotion

Total No. of Libraries

Reporting Performance

of Voluntary Overtime

Consider this as a Factor

in Evaluation for Merit

Increase

Yes

No

Consider this as a Factor

in Evaluation for Promotion

Yes

No

neth R. Schaffer has made the same point in several of his case studies. ${ }^{15}$

The primary purpose of this study was to determine how overtime performed by librarians is handled in New York State academic libraries. It is felt that the responses to the survey provide a good general indication of the existing conditions in this area. None of the survey's questions dealt with the effect of overtime on the librarian's professional obligations and development. Nor did

15 Kenneth R. Shaffer, Library Personnel Administration and Supervision (2d ed. rev. and enl.; "Case Studies in Library Administration, Series 1"; Hamden, Conn.: Shoe String Press, 1963), p. 28-36, 16167. While Shaffer's "cases" are fictional composites, they were prepared from factual data. As such, they are valid illustrations of the point of view expressed by the two librarians quoted.

\section{TABLE 7}

Relationship Between Number of Hours Per WeEk Which Library Is Open and Performance OF Required or VOLUNTARY OVERTIME

\begin{tabular}{|c|c|c|c|c|c|c|c|}
\hline \multicolumn{3}{|c|}{$\begin{array}{l}\text { No. of HoURs PER } \\
\text { WEEK LIBRARY Is } \\
\text { OPEN }\end{array}$} & & \multicolumn{2}{|c|}{$\begin{array}{l}\text { REQUIRED } \\
\text { OVERTIME } \\
\text { PERFORMED }\end{array}$} & \multicolumn{2}{|c|}{$\begin{array}{l}\text { VOLUNTARY } \\
\text { OVERTIME } \\
\text { PERFormed }\end{array}$} \\
\hline & & & & Yes & No & Yes & No \\
\hline $\begin{array}{l}40-70 \\
71-80 \\
81-90 \\
91-104 \\
\text { Totals }\end{array}$ & $:$ & : & & $\begin{array}{r}11 \\
18 \\
10 \\
5 \\
44\end{array}$ & $\begin{array}{r}5 \\
1 \\
6 \\
0 \\
12\end{array}$ & $\begin{array}{r}14 \\
17 \\
16 \\
5 \\
52\end{array}$ & $\begin{array}{l}2 \\
2 \\
0 \\
0 \\
4\end{array}$ \\
\hline
\end{tabular}


TABLE 8

Relationship Between Number of Full Time Professional Staff Members and Performance of Required or Voluntary OVERTIME

\begin{tabular}{|c|c|c|c|c|c|c|c|c|c|}
\hline \multicolumn{6}{|c|}{$\begin{array}{l}\text { No. of Professional } \\
\text { Staff Members }\end{array}$} & \multicolumn{2}{|c|}{$\begin{array}{l}\text { REQUIRED } \\
\text { OVERTIME } \\
\text { PERFoRMEd }\end{array}$} & \multicolumn{2}{|c|}{$\begin{array}{l}\text { Voluntary } \\
\text { Overtime } \\
\text { PERFormed }\end{array}$} \\
\hline & & & & & & Yes & No & Yes & No \\
\hline $1-5$ & - & & - & . & . & 19 & 11 & 26 & 4 \\
\hline $6-10$ & - & & . & & & 16 & 1 & 15 & 2 \\
\hline $11-15$ & . & & . & . & . & 5 & 1 & 6 & 0 \\
\hline $16-35$ & . & . & . & . & . & 4 & 0 & 4 & 0 \\
\hline $36-60$ & . & . & . & . & . & 3 & 1 & 4 & 0 \\
\hline $61-130$ & 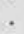 & . & . & . & . & 1 & 0 & 1 & 0 \\
\hline Totals & . & . & . & . & . & 48 & 14 & 56 & 6 \\
\hline
\end{tabular}

the survey attempt to elicit any comment upon the individual librarian's attitude toward the performance of overtime. While a detailed discussion of these corollary topics is outside the scope of this study, some general observations will be made.

It should be recognized that certain types of overtime are unavoidable, e.g., filling in for a co-worker who is ill, completion of a specific project which carries a deadline, elimination of a back$\log$ which has developed out of circumstances beyond the library's control, etc. Beyond this point, however, overtime should be neither required nor encouraged. Numerous references may be cited, in the literature of librarianship as well as that of personnel management, which indicate that overtime is not the best, nor even a good, way to handle the problem of a continuing excessive workload. Lyle has observed, "If a thirty-eight hour week does not meet the library's need, then the librarian should seek additional staff and not overtax the present personnel at the expense of the quality of library service."16 Littlefield and Peterson note that overtime is one of the common ways of handling peak load (in industry). They conclude, however, that "Sometimes this may be the only way

\footnotetext{
${ }^{10}$ Guy R. Lyle, The Administration of the College
} Library (New York: Wilson, 1961), p. 197-98. out, but unit costs during overtime are usually found in production studies to be just about double their amount during regular time. This suggests rather forcefully that overtime should be the last resort rather than the first resort."17 Also, while there is little or no evidence to support the popular assumption that job satisfaction or morale contribute to productivity, ${ }^{18}$ Rensis Likert has observed, ". . . that the combination of high productivity with low satisfaction [a very probable concomitant of prolonged overtime] over long periods may be difficult or impossible to maintain because it means consumption and deterioration of the organization's human assets."19 Read quality of service for productivity and you have a very likely explanation for the instance where a highly capable librarian snaps at a patron's poorly phrased question because she has been serving fifty hours a week on duty. Finally, the performance of voluntary overtime, which is often considered a mark of devotion to duty or

(Continued on page 239)

${ }^{17} \mathrm{C}$. L. Littlefield and R. L. Peterson, Modern Office Management (Englewood Cliffs, N. J.: Prentice-Hall, 1956), p. 387 .

18 Robert L. Kahn, "Produetivity and Job Satisfaction," Personnel Psychology, XIII (Autumn 1960), $275-87$.

Edward K. Strong, Jr., "Satisfactions and Interests," American Psychologist, XIII (1958), 449-56.

F. D. Harding and R. A. Bottenberg, "Effect of Personal Characteristics on Relationships Between Attitudes and Job Performance," Journal of Applied Psychology, XLV (December 1961), 428-30.

$10 \mathrm{Kahn}$, op. cit., p. 286 , citing Rensis Likert.

TABLE 9

Bases Upon Which Voluntary Overtime Is PERFORMED

BAsis No. of LIBRARTES

As a regular practice 2

Seldom or occasionally 31

Dependent upon work load 21

Independent of work load

At one time or another by most staff members

Frequently or regularly by a few (generally the same) staff members . 
of the initial nine factors analyzed seemed to have no particular relevance to success. That was the consideration of the undergraduate major.

Of course, other factors no doubt had effects upon the success or non-success of these two groups. New or unexpected responsibilities in the home or on the job, family illness, and financial embarassment took their toll in both groups.

\section{ACRL Membership}

President, Helen M. Brown; College Libraries Section Chairman, Martha L. Biggs; Junior College Libraries Section Chairman, Harriett Genung; Rare Books Section Chairman, Marcus A. McCorison; Subject Specialists Section Chairman, James Humphry, III; University Libraries Section Chairman, Everett T. Moore. ACRL Executive Secretary, George M. Bailey, 50 East Huron St., Chicago 60611.

\section{OVERTIME . . .}

(Continued from page 200)

"professional involvement," may have decidedly less pleasant implications. Shaffer cites a case of a staff worker who used the fact that she did not take her authorized breaks to "prove" that she actually worked longer than other staff members. ${ }^{20}$ Nigel Walker, in a study of morale in the British Civil Service, notes that among the higher level of office workers (career personnel), the act of working for longer hours than most of their colleagues was a means of acquiring merit, and even some sort of moral advantage over them. ${ }^{21}$

In conclusion, it is felt that overtime, while its performance when necessary should be recognized and rewarded, is not and should not be considered as a substitute for continuing professional development or the performance of professional obligations. To use the number of hours worked, irrespective of the nature of the work, as a criterion for evaluating a professional's performance is to deny the validity of the concept that he is rewarded for his service, not his time. Where the performance of overtime, voluntary or required, would detract from such development, it should not be required if at all possible; at the least it should not be encouraged. Where the performance of overtime cannot be avoided, compensatory time should be allowed, not on an hour-for-hour basis but in such a way as to permit the librarian concerned to continue his professional development.

In an era of continuing shortages of professional personnel, overtime is obviously a necessary evil. But it should not be allowed to perpetuate itself through a refusal to admit that the evil exists.

ACRL Membership May 10, 1966 . 9662

Section memberships, March 31, 1966

College ........... 2943

Junior College ......... 946

Rare Books ........... 1138

Subject Specialists $\ldots \ldots \ldots 1947$

University ........... 3655

Institutional memberships, March

31, 1966

${ }^{20}$ Shaffer, op. eit., p. 74-78.

2 Nigel Walker, Morale in the Civil Service (Edinburgh: At the University Press, 1961), p. 167. Walker also observes that, "To be more hard working in this or other ways confers similar advantages, particularly if-like justice-it is not only done but seen to be done." p. 231 . 